\title{
RECOGNITION AND PERCEPTION OF LATVIA AS A TOURISM DESTINATION IN DIFFERENT SEGMENTS
}

\author{
Ilze Medne ${ }^{1}$, Dr.oec., Assist.prof., senior researcher; Kristine Berzina², MBA, Lecturer, \\ researcher \\ 1,2University of Latvia, Faculty of Business, Management and Economics
}

\begin{abstract}
Recognition and perception as well as the image of a destination plays a significant role in choosing a specific destination for a potential journey. The destination image includes different attributes - tangible and verifiable destination attributes, as well as more intangible aspects as perceptions of a more psychological nature and emotions related to particular destination. The aim of the research was to study differences in the recognition and perception of Latvia as a tourism destination in different segments of potential European travellers in Latvia's target markets and how they affect their intentions to visit Latvia.

The research involved data of three face-to-face surveys conducted in different places of Germany, Switzerland and Austria in 2015, 2016 and 2017. The questionnaire was conducted to evaluate the recognition and the perception of Latvia as tourism destination as well as to find out the respondents' intentions to visit Latvia within the next three years.

As tool for data analyses SPSS software was used by applying descriptive statistics, data correlation and crosstabulations. Main results and findings are intended for organisations that are responsible for tourism image development in Latvia, to optimize marketing communication with different tourist segments in countries mentioned above.
\end{abstract}

Key words: destination, image, recognition, perception, destination attributes.

JEL code: M31, L83.

\section{Introduction}

Several authors (Holloway, 1986; Shih, 1986 etc.) have tried to investigate the features of the destination tourism product. The reason is that tourists usually have incomplete knowledge about a destination that they have not visited, and they often make their choice on the basis of symbolic information from the media or from social networks (Ragavan, Subramoniana, Sharif, 2014).

Pre-purchase behavioural studies identify tourists' motivations, destination images, and tourists' decision-making behaviours that provide critical insights into future product development and promotional schemes (Chen, 2003). Particular destination can only match certain types of demand. Thus, destinations need to know and understand the needs and aspirations of potential tourists to manage destination resources and attract the right customer groups. Segmentation is usually used to get a better position compared to competitors, because it provides valuable information on customers and allows the destination to tailor its offer to better meet customer needs (Pesonen, Laukkanen, Komppula, 2011).

The aim of the study was to find out the differences in the recognition and perception of Latvia as a tourism destination in different segments of potential travellers in Latvia's target markets in Europe and how they affect their intentions to visit Latvia.

\section{Destination image and positioning}

According to Fakeye and Crompton (1991), destination image is an individual's mental representation of knowledge, feelings and overall perception of a particular destination. Positioning is the process of creating a distinctive place for a destination in the minds of the potential visitors in the targeted markets. Comparative images of tourist destinations can be identified by comparing several competing destinations. In this process, the strengths and weaknesses of the destinations, 
the competitive advantages and the different competencies for each destination in relation to other potential destinations are determined. The development of a positioning strategy involves several stages: firstly, identifying existing destination images in target market segments, secondly, comparing these images with competitor images, and thirdly, selecting destination features that meet the needs and wishes of travellers and distinguishing a destination from competitors (Baloglu, McCleary, 1999). As destinations usually consist of diverse range of features and not all can be included in the positioning, decisions should be made about which attributes are important (Pike, 2012). If the destination is not differentiated from competing destinations, then the likelihood that it will be considered as a possible destination will be reduced and that it will indeed be chosen as the final destination in the travel decision-making process. One of the specific interests of the destination image research is to identify the strengths and weaknesses of tourist destinations compared to other destinations based on perceived destination features and / or perceived similarities between destinations without reference to specific destination features. Other studies have looked at the differences between travellers who visited the destination (visitors) and those who did not (nonvisitors) (Fridgen 1987; Chon 1990; Ahmed 1991; Fakeye and Crompton, 1991; Hu and Ritchie, 1993; Milman and Pizam, 1995; Baloglu, McCleary, 1999). Destination marketing organizations should develop different destination image and positioning strategies in the target markets, taking into account that both these groups may need different positioning and communication strategies. The destination image, perceived by its actual and potential visitors, plays an important role in determining its competitiveness as a tourist destination.

\section{Segmentation specifics in tourism industry}

Ragavan, Subramoniana, Sharif (2014) indicated that better understanding of the needs and motives of tourists and adjusting conditions accordingly can lead to more successful destination marketing.

According to Heung and Quf (2000) and Ragavan, Subramoniana, Sharif (2014), an understanding of the preferences and travel related behaviour of tourists is vital for tourism marketing in terms of market segmentation and the design of effective promotional campaign (Ragavan, Subramoniana, Sharif, 2014).

Market segmentation in tourism can be defined as a process of dividing a common tourist market into distinct groups of tourists who could demand distinctive experiences or particular marketing service mixes. In tourism studies segmentation generally includes diverse tourist characteristics such as demographics, socio-economic factors, country of origin as geographical criteria, and particular tourism product related behavioural characteristics for instance purchasing and consumption behaviour aspects, tourism attraction preferences and attitudes towards them, need for particular experiences and services (Kotler, 2003; Bloom, 2004). To effectively meet the needs of certain tourist segments, many studies have been carried out to explore and identify the specific characteristics of particular segments of tourists or tourist similarities in a particular segment (Hudson, 2000; Shoemaker, 1994). For segmenting tourists, researchers have used prior (Hudson, 2000) and post hoc analyses (Koca, Altinay, 2007).

Tourists are heterogeneous in the perception of their travel elements and features. Travel elements and features may be perceived differently by tourists from particular cultures and different countries (Chen \& Kerstetter, 1999). As stated by Baloglu and McCleary (1999), perception of tourist destination image can differentiate for various individual's age groups. The same can be true from 
gender perspective - as indicated in one study the on destination image of Pennsylvania by Chen and Kerstetter (1999) where rural tourism destination analyses demonstrated significant tourist gender influence on the destination perceived image. Women could perceive more intensively intrapersonal constraints and could be short on skills and knowledge about opportunities, the research of Jackson and Henderson (1995) indicated that women scored higher on the interpersonal and intrapersonal constraint dimensions (Hudson, 2000).

As reported by wide range of marketing scholars socio-demographic factors such as gender, age and marital status could play significant role in consumer behaviour (Ragavan, Subramoniana, Sharif, 2014). On overall, market segmentation in tourism marketing is considered by scholars as crucial research and therefore repeatedly investigated both by academic researchers and also practitioners (Chen, 2003). Determination of the strength of relationship for particular tourist segment in relation with certain criterion of interest can be used by marketers for efficient work for particular target market development. As example can be mentioned intention to buy as a dependent variable, then the aim could be to find particular segment that has the highest probability to buy indicating the most valuable tourist segment for destination (Chen, 2003).

Destination Marketing Organisation representatives when developing marketing strategy frequently face a challenge to select the most suiTable methodology for tourism destination market segmentation. Market segmentation has been extensively used to understand the distinct characteristics of tourists and for developing marketing strategies.

Customer segmentation can be declared as a very significant data mining methodologies used in marketing and also in customer relationship management as behavioural clustering and segmentation help drive strategic marketing initiatives, while particular sociodemographic segmentation could be applied in tactical destination marketing (Bloom, 2004). As indicated by LunaCortés (2018), recent research is directed to analyse the influence of the internet marketing, especially online content marketing, on the image of a country. It should be indicated that there are two different approaches how we conduct market segmentation process - it can be done a priori as common sense segmentation and a posteriori as a data-driven segmentation (Dolnicar and Grun, 2008). As stated by Dolnicar and Grun (2008), in the case of priori or common sense segmentation it is important to start with choice of the segmentation criteria, while in a posteriori segmentation this burden of responsibility rests with the research approach of the data-driven segmentation study undertaken. Particularly in tourism marketing research, segments have often been identified according to prior knowledge (Dolnicar, 2004). Both prior and posteriori segmentation approaches have been used in several market segmentation studies in tourism, still use of age, income, or country of origin, geographic location and stage in the family life cycle, nationality or visitors' participation in certain activities as criteria is more common for tourism market segmentation, nevertheless in each particular research choice has to be validated (Pesonen, Laukkanen, Komppula, 2011).

The tourism marketing research indicates that the tourism market has a very heterogeneous nature and thus different activities at the tourism destination will appeal to different types of tourists. Therefore, Destination Marketing Organisation representatives need to be aware of different tourists' needs, wants, and preferences by developing a wide variety of facilities, tailored packages and diverse services for tourists. Market segmentation technique can be applied in heterogeneous markets and each tourist segment can be seen as smaller homogeneous groups distinguished by abovementioned criteria - geographic, sociodemographic, psychographic, behavioural aspects, still 
needs to be mentioned that each segment needs not only to be enough substantial and accessible, but also quantitatively measurable, so that Destination Marketing Organisation representatives can efficiently targeted them through specific marketing campaigns (Tkaczynski, Rundle-Thiele, Prebensen, 2015).

After the segmentation, next step that follows is targeting particular tourist markets. Target marketing mainly is defined as a strategy that aims at grouping a major market into segments with the aim to target one or more most profiTable segments or to develop products and marketing programmes adjusted to each distinctive segment (Kotler, 2003; Bloom, 2004).

Thus summarising, in the consumer segmentation studies tourism marketing scholars divide consumers into groups which are homogeneous within the group but substantially different from other groups, assuming a heterogeneous overall tourism market, often working with quantitative research methods by using surveys for data collection offering significant practical relevance to marketers, enabling tourism organisations and companies to target chosen market segments and then position their own product in accordance (Lutz, Newlands, 2018).

\section{Methodology}

In overall marketing literature as well as in tourism marketing studies it has been discussed on the techniques applied for segmentation (D'Urso, Disegna, Massari, Osti, 2016). Tourism marketing literature related to segmentation issues indicates domination in use of psychographic variables such as tourist motivation for travel, personal opinions and judgements about destination and offered services. Quite often these psychographic variables are gathered by using qualitative scales, usually Likert scale or similar because of the easiness of application when developing and administering the data. Still some allow to obtain only an imprecise measurement of the subjective perception of the respondent. Nevertheless, the scale approach gives possibility to gather quite imprecise data because of the subjective scale perception of the traveller, few segmentation studies on tourism have taken into consideration the uncertainty and vagueness that generally characterize qualitative scales (D'Urso, Disegna, Massari, Osti, 2016).

In era of global competition when tourists have hundreds of destinations as choices for their travel, for the developing destinations it is important to target different market segments including wide range of potential tourists who have not yet visited the country. In order to have successful marketing communication for new potential tourist attraction the work with destination perception in each market segment is crucial.

The research question of the study investigates what are the differences in the perception of Latvia as a destination between genders and age groups, and whether the perception of the destination influences the decision to travel to Latvia.

Quantitative research analyses method was applied using data of three face-to-face surveys conducted in 2015, 2016 and 2017. The questionnaire was developed to investigate the recognition and the perception of tourism destination Latvia as well as to find out the respondents' intentions to visit Latvia within the next three years. The survey was conducted in three European countries Germany, Switzerland and Austria. Interview comprised 1260 inhabitants, 1183 or $94 \%$ of which have never been in Latvia. The detailed respondents profile is indicated in the Table 1. 
Respondent's profile $(\%, n=1183)$

\begin{tabular}{|l|c|c|}
\hline \multicolumn{2}{|c|}{ Indicator } & $\begin{array}{c}\text { Share in the total number of } \\
\text { respondents }\end{array}$ \\
\hline \multirow{3}{*}{ Gender } & male & $44 \%$ \\
\hline \multirow{4}{*}{ Age } & female & $56 \%$ \\
\cline { 2 - 3 } & $18-24$ & $52 \%$ \\
\cline { 2 - 3 } & $25-44$ & $37 \%$ \\
\cline { 2 - 3 } & $45-64$ & $8 \%$ \\
\cline { 2 - 3 } & $65+$ & $3 \%$ \\
\hline \multirow{4}{*}{ Education } & professional & $18 \%$ \\
\cline { 2 - 3 } Income level in comparison with average & high school & $25 \%$ \\
\cline { 2 - 3 } income in the country of origin & university/ high & $48 \%$ \\
\cline { 2 - 3 } & school degree & $9 \%$ \\
\cline { 2 - 3 } & other & $29 \%$ \\
\cline { 2 - 3 } & below average & $49 \%$ \\
\cline { 2 - 3 } & above average/ high & $22 \%$ \\
\hline
\end{tabular}

Source: calculations made by authors based on 2015, 2016, 2017 year survey data

For further analyses data on respondents who have not been in Latvia, will be analysed. For the segmentation used in research was gender and four age groups: from 18 to 24 old, 25 - 44, 45 64 and 65 and older. For the date analyses, SPSS software tools were used by applying descriptive statistics, data correlation as well as crosstabulation. Main research results and findings are addressed towards Destination Marketing Organisations whose reasonability is tourism image development in Latvia, to optimize marketing communication with different tourist segments in countries mentioned above.

\section{Research result analysis and findings}

In order to reach the aim of the study, questions about the perception of Latvia as a destination and travel intentions in the next three years were asked: 'How well do you know Latvia?', 'What are your thoughts about Latvia as a tourist destination as a whole?', 'Do you plan to travel to Latvia in the next 3 years?' It was given the opportunity to respond, using the 7-point Likert scale. The research results were analysed by dividing the genders and 4 age groups (Table 2 ).

\section{European respondent's perception of Latvia as a destination and travel intentions in the next three years (mean)}

\begin{tabular}{|c|c|c|c|c|c|c|c|}
\hline & \multirow{2}{*}{ Total } & \multicolumn{2}{|c|}{ Gender } & \multicolumn{4}{|c|}{ Age groups } \\
\hline & & Female & Male & $18-24$ & $25-44$ & $45-64$ & $65+$ \\
\hline $\begin{array}{l}\text { Familiarity with destination } \\
\text { (in the scale from } 1 \text {-not at all to } \\
7 \text {-very well) }\end{array}$ & 1.83 & 1.74 & 1.95 & 1.89 & 1.84 & 1.60 & 1.40 \\
\hline $\begin{array}{l}\text { Attitude towards Latvia as a } \\
\text { tourism destination } \\
\text { (in the scale from } 1 \text {-very negative } \\
\text { to } 7 \text {-very positive) }\end{array}$ & 4.61 & 4.65 & 4.57 & 4.53 & 4.64 & 4.92 & 5.26 \\
\hline $\begin{array}{l}\text { Do you plan to travel to Latvia } \\
\text { in the next } \mathbf{3} \text { years? } \\
\text { (in the scale from } 1 \text {-definitely not } \\
\text { to } 7 \text {-definitely yes) }\end{array}$ & 3.27 & 3.26 & 3.27 & 3.07 & 3.41 & 3.85 & 3.76 \\
\hline
\end{tabular}

Source: calculations made by authors based on 2015, 2016, 2017 year survey data

Although respondents indicated knowledge about Latvia was different in different age groups the older were respondents, the lower they indicated their knowledge about Latvia, the attitude towards Latvia as destination and plans to travel were increasing by age. 
Correlation between familiarity with destination, attitude towards Latvia as a tourism destination and intentions to travel to Latvia was applied using Spearmen correlation calculation (Table 3).

Table 3

\section{Correlation between familiarity with destination, attitude towards Latvia as a tourism destination and intentions to travel to Latvia (Spearman)}

\begin{tabular}{|c|c|c|c|c|c|c|c|}
\hline & & $\mathbf{G e}$ & & & Age & oups & \\
\hline & Total & Female & Male & $18-24$ & $25-44$ & $45-64$ & $65+$ \\
\hline $\begin{array}{l}\text { Familiarity with } \\
\text { destination }\end{array}$ & $.192 * *$ & $.198 * *$ & $.188 * *$ & $.213^{* *}$ & $.187^{* *}$ & $.324 * *$ & -.113 \\
\hline $\begin{array}{l}\text { Attitude towards Latvia } \\
\text { as a tourism destination }\end{array}$ & $.441 * *$ & $.459 * *$ & $.411 * *$ & $.438 * *$ & $.421 * *$ & $.452 * *$ & .196 \\
\hline
\end{tabular}

** Correlation is significant at the 0.01 level (2-tailed)

Source: calculations made by authors based on 2015, 2016, 2017 year survey data

Analyses indicated that there is positive correlation between attitude towards Latvia as tourism destination and intention to travel for all segments except age group 65 and older. Slightly closer correlation between attitude and intention to travel was for female segment and 45-64 years old travellers. Regarding the familiarity with destination and intention to travel did not indicated significant level of correlation.

The opinion about Latvia from a potential tourist point of view was analysed using question "please give your opinion about Latvia from a tourist point of view" where neutral evaluation was indicated by 4 , and positive opinion can be described from 5 to 7 . To indicate certain segment positive opinion - segments with positive opinion and mean higher than for all respondents were highlighted (Table 4).

Positive opinion in overall perception is green country with unspoiled nature (higher mean is for female and age groups over 45 years old), country with rich cultural heritage (female and age groups 25-64), beautiful cities and villages (female and age groups 25-64), good recreation facilities (female and age groups 18-24), relaxing atmosphere (female and age groups 18-24), friendly and hospiTable locals (female and age groups 18-24, 45-64), Interesting cultural attractions (female and age groups 25 and older), interesting historical attractions (female and age groups 25 and older), high personal safety (female and age groups 18-24), appealing local food local cuisine (female and age groups 18-24), good value for money (man and age groups 25 and older). For few segments opinion about Latvia as tourism destination differs from average perception (that was below 5) long seashore, beautiful beaches (higher result is for 45 and older), good entertainment and nightlife (higher result is for 45 and older), high cleanliness (men and 18-24, 65 and older), high service quality (45-64), low prices of tourism services (men and 25-64). 
Opinions about Latvia from a potential tourist point of view (mean in the scale from 1 - fully disagree to 7 - completely agree)

\begin{tabular}{|c|c|c|c|c|c|c|c|}
\hline \multirow{2}{*}{ Characteristics } & \multirow{2}{*}{ Total } & \multicolumn{2}{|c|}{ Gender } & \multicolumn{4}{|c|}{ Age groups } \\
\hline & & Female & Male & $18-24$ & $25-44$ & $45-64$ & $65+$ \\
\hline $\begin{array}{l}\text { Green country with } \\
\text { unspoiled nature }\end{array}$ & 5.43 & 5.52 & 5.33 & 5.42 & 5.42 & 5.51 & 6.00 \\
\hline $\begin{array}{l}\text { Long seashore, beautiful } \\
\text { beaches }\end{array}$ & 4.68 & 4.77 & 4.55 & 4.50 & 4.79 & 5.30 & 5.31 \\
\hline $\begin{array}{l}\text { Country with rich cultural } \\
\text { heritage }\end{array}$ & 5.11 & 5.21 & 4.98 & 5.00 & 5.21 & 5.39 & 5.11 \\
\hline Beautiful cities and villages & 5.39 & 5.49 & 5.26 & 5.38 & 5.40 & 5.45 & 5.21 \\
\hline $\begin{array}{l}\text { Good entertainment, } \\
\text { nightlife }\end{array}$ & 4.67 & 4.62 & 4.73 & 4.48 & 4.87 & 5.04 & 5.13 \\
\hline Good recreation facilities & 5.24 & 5.32 & 5.15 & 5.32 & 5.19 & 5.02 & 4.78 \\
\hline $\begin{array}{l}\text { Well suited for family } \\
\text { holidays }\end{array}$ & 4.95 & 4.98 & 4.89 & 4.98 & 4.92 & 4.86 & 4.46 \\
\hline Relaxing atmosphere & 5.45 & 5.47 & 5.43 & 5.51 & 5.45 & 5.09 & 5.07 \\
\hline Exciting atmosphere & 4.56 & 4.54 & 4.57 & 4.44 & 4.68 & 4.92 & 4.08 \\
\hline Friendly, hospiTable locals & 5.60 & 5.64 & 5.57 & 5.61 & 5.56 & 5.82 & 5.38 \\
\hline $\begin{array}{l}\text { Good opportunities for } \\
\text { shopping }\end{array}$ & 4.27 & 4.27 & 4.27 & 4.20 & 4.35 & 4.71 & 3.45 \\
\hline $\begin{array}{l}\text { Interesting cultural } \\
\text { attractions }\end{array}$ & 5.16 & 5.18 & 5.13 & 5.03 & 5.31 & 5.38 & 5.42 \\
\hline $\begin{array}{l}\text { Interesting historical } \\
\text { attractions }\end{array}$ & 5.20 & 5.27 & 5.10 & 5.10 & 5.30 & 5.38 & 5.38 \\
\hline $\begin{array}{l}\text { High quality of } \\
\text { accommodation }\end{array}$ & 4.70 & 4.66 & 4.74 & 4.73 & 4.76 & 4.53 & 4.38 \\
\hline $\begin{array}{l}\text { High quality of } \\
\text { infrastructure }\end{array}$ & 4.51 & 4.49 & 4.53 & 4.54 & 4.45 & 4.67 & 4.11 \\
\hline High cleanliness & 4.95 & 4.87 & 5.07 & 5.08 & 4.77 & 4.88 & 5.00 \\
\hline High personal safety & 5.05 & 5.11 & 4.97 & 5.17 & 4.93 & 4.85 & 4.64 \\
\hline $\begin{array}{l}\text { Appealing local food, local } \\
\text { cuisine }\end{array}$ & 5.16 & 5.21 & 5.10 & 5.20 & 5.12 & 5.12 & 4.75 \\
\hline High service quality & 4.89 & 4.97 & 4.80 & 4.96 & 4.76 & 5.12 & 4.78 \\
\hline Good value for money & 5.20 & 5.10 & 5.34 & 5.10 & 5.32 & 5.35 & 5.25 \\
\hline $\begin{array}{l}\text { Low prices of tourism } \\
\text { services }\end{array}$ & 4.98 & 4.90 & 5.09 & 4.89 & 5.10 & 5.11 & 4.91 \\
\hline
\end{tabular}

Source: calculations made by authors based on 2015, 2016, 2017 year survey data

Correlation between opinions about Latvia from a tourist point of view and intentions to travel to Latvia in the next 3 years was carried out (Table 5 ). 


\section{Correlation between opinions about Latvia from a tourist point of view and intentions to travel to Latvia (Spearman)}

\begin{tabular}{|c|c|c|c|c|c|c|c|}
\hline \multirow{2}{*}{ Characteristics } & \multirow{2}{*}{ Total } & \multicolumn{2}{|c|}{ Gender } & \multicolumn{4}{|c|}{ Age groups } \\
\hline & & Female & Male & $18-24$ & $25-44$ & $45-64$ & $65+$ \\
\hline $\begin{array}{l}\text { Green country with } \\
\text { unspoiled nature }\end{array}$ & $.136 * *$ & $.144 * *$ & $.104^{*}$ & $.129 * *$ & $.129 *$ & .148 & .179 \\
\hline $\begin{array}{l}\text { Long seashore, beautiful } \\
\text { beaches }\end{array}$ & $.192 * *$ & $.152 * *$ & $.234^{* *}$ & $.138 * *$ & $.231^{* *}$ & $.294^{*}$ & -.096 \\
\hline $\begin{array}{l}\text { Country with rich cultural } \\
\text { heritage }\end{array}$ & $.113^{* *}$ & $.121^{* *}$ & .094 & .056 & $.186 * *$ & .043 & .063 \\
\hline $\begin{array}{l}\text { Beautiful cities and } \\
\text { villages }\end{array}$ & $.128 * *$ & $.112 * *$ & $.137^{* *}$ & $.111^{*}$ & .080 & $.415 * *$ & .328 \\
\hline $\begin{array}{l}\text { Good entertainment, } \\
\text { nightlife }\end{array}$ & $.076 *$ & .060 & .088 & .054 & .046 & $.319 *$ & .217 \\
\hline Good recreation facilities & $.132 * *$ & $.101^{*}$ & $.159 * *$ & $.142 * *$ & $.124^{*}$ & .142 & .649 \\
\hline $\begin{array}{l}\text { Well suited for family } \\
\text { holidays }\end{array}$ & $.098 * *$ & $.102 *$ & .086 & $.136 * *$ & .057 & -.047 & $.557 *$ \\
\hline Relaxing atmosphere & $.114^{* *}$ & $.094^{*}$ & $.112 *$ & $.146 * *$ & $.148 * *$ & -.231 & .060 \\
\hline Exciting atmosphere & $.177^{* *}$ & $.162 * *$ & $.186 * *$ & $.155^{* *}$ & $.203 * *$ & .195 & .227 \\
\hline Friendly, hospiTable locals & $.116 * *$ & $.117^{* *}$ & .089 & $.148 * *$ & .075 & .056 & -.004 \\
\hline $\begin{array}{l}\text { Good opportunities for } \\
\text { shopping }\end{array}$ & $.158 * *$ & $.156 * *$ & $.153^{* *}$ & $.136 * *$ & $.148^{*}$ & $.340 *$ & -.132 \\
\hline $\begin{array}{l}\text { Interesting cultural } \\
\text { attractions }\end{array}$ & $.119 * *$ & $.154 * *$ & .053 & $.100 *$ & $.127^{*}$ & -.033 & -.007 \\
\hline $\begin{array}{l}\text { Interesting historical } \\
\text { attractions }\end{array}$ & $.157^{* *}$ & $.145^{* *}$ & $.164^{* *}$ & $.125^{* *}$ & $.197 * *$ & .064 & -.094 \\
\hline $\begin{array}{l}\text { High quality of } \\
\text { accommodation }\end{array}$ & $.151^{* *}$ & $.098 *$ & $.227^{* *}$ & $.160 * *$ & $.175^{* *}$ & .146 & -.237 \\
\hline $\begin{array}{l}\text { High quality of } \\
\text { infrastructure }\end{array}$ & $.147^{* *}$ & $.124^{*}$ & $.169 * *$ & $.106 *$ & $.178 * *$ & $.354 *$ & -.190 \\
\hline High cleanliness & $.088^{*}$ & $.104^{*}$ & .053 & $.096 *$ & .065 & .248 & .191 \\
\hline High personal safety & .046 & .000 & .073 & .032 & .064 & .242 & .098 \\
\hline $\begin{array}{l}\text { Appealing local food, local } \\
\text { cuisine }\end{array}$ & $.105^{* *}$ & $.132 * *$ & .048 & $.113^{*}$ & .102 & .062 & .390 \\
\hline High service quality & .065 & .038 & .071 & .087 & -.037 & .243 & $.752 *$ \\
\hline Good value for money & $.099 * *$ & .084 & $.128 *$ & .093 & .085 & .044 & .592 \\
\hline $\begin{array}{l}\text { Low prices of tourism } \\
\text { services }\end{array}$ & .042 & .022 & .078 & .064 & -.001 & -.210 & $.740 * *$ \\
\hline
\end{tabular}

* Correlation is significant at the 0.05 level (2-tailed)

** Correlation is significant at the 0.01 level (2-tailed)

Source: calculations made by authors based on 2015, 2016, 2017 year survey data

Results indicate that the highest intention to travel to Latvia was for age group 45-64, and in this particular segment correlation between opinions about Latvia and intentions to travel was for following aspects beautiful cities and villages, good opportunities for shopping, high quality of infrastructure.

As the highest correlation between opinions about Latvia and intentions to travel to Latvia is in segment of 65 years and older in the aspects of quality and price ratio - high service quality, good value for money spent, low prices of tourism services and good recreation facilities. 


\section{Conclusions, proposals, recommendations}

The study concludes that different segments of potential tourists may have different perceptions of Latvia as a travel destination. By promoting Latvia in the European tourism market, it is purposeful to choose different accents for different segments: for seniors - service quality and low prices of tourism services (good value for money), good recreation possibilities; for middle-aged tourists beautiful cities and villages, high quality of infrastructure; for younger tourists - long seashore, beautiful beaches, exciting atmosphere.

\section{Bibliography}

1. Ahmed, Z.U., 1991. The Influence of the Components of a State's Tourist Image on Product Positioning Strategy. Tourism Management, 12(4), pp.331-340.

2. Baloglu, S., McCleary K.W., 1999. U.S. International Pleasure Travellers' Images of Four Mediterranean Destinations: A Comparison of Visitors and Nonvisitors. Journal of Travel Research, 38(11), pp.144-152.

3. Bloom, J.Z., 2004. Tourist Market Segmentation with Linear and Non-linear Techniques. Tourism Management, 25, pp.723-733.

4. Chen, J.S. 2003. Market Segmentation by Tourists Sentiments, Annals of Tourism Research, 30(1), pp.178193.

5. Chen, p. J., Kerstetter, D. L., 1999. International Student's Image of Rural Pennsylvania as a Travel Destination. Journal of Travel Research, 37(3), pp.256-266.

6. Chon, K.S., 1990. The Role of Destination Image in Tourism: A Review and Discussion. The Tourist Review, $45(2)$, pp.2-9.

7. Dolnicar, S., 2004. Beyond "Common Sense Segmentation" - A Systematics of Segmentation Approaches in Tourism. Journal of Travel Research, 42(3), pp.244-250.

8. Dolnicar, S., Grun, B., 2008. Challenging 'Factor Cluster Segmentation'. Journal of Travel Research, 47(1), pp.63-71.

9. D'Urso, P., Disegna, M., Massari, R., Osti, L., 2016. Fuzzy Segmentation of Postmodern Tourists. Tourism Management, 55, pp.297-308.

10. Fakeye, p. C., Crompton, J. L., 1991. Image Differences between Prospective, First-time, and Repeat Visitors to the Lower Rio Grande Valley. Journal of Travel Research, 30, pp.10-16.

11. Fridgen, J.D., 1987. Use of Cognitive Maps to Determine Perceived Tourism Regions, Leisure Sciences, 9 (2), pp.101-117.

12. Heung, V. C. S., Quf, H., 2000. Hong Kong as a Travel Destination: An Analysis of Japanese Tourists' Satisfaction Levels, and the Likelihood of them Recommending Hong Kong to Others. Journal of Travel and Tourism Marketing, 9(1/2), pp.57-80.

13. Holloway, J. C., 1986. The Business of Tourism. London: Longman Publishing Ltd.

14. Hudson, S., 2000. The Segmentation of Potential Tourists: Constraint Differences between Men and Women. Journal of Travel Research, 38(5), pp.363-368.

15. Koca, E., Altinay, G., 2007. An Analysis of Seasonality in Monthly per Person Tourist Spending in Turkish Inbound Tourism from a Market Segmentation Perspective. Tourism Management 28, pp.227-237.

16. Kotler, P., 2003. Marketing Management. 11th Edition, Prentice-Hall, Upper Saddle River, 738 p.

17. Luna-Cortés, G., 2018. Differences among Generations of USA Tourists Regarding the Positive Content Created about Colombia in Social Media. Journal of Hospitality and Tourism Management, 36, pp.31-39.

18. Lutz, C., Newlands, G., 2018. Consumer Segmentation within the Sharing Economy: The Case of Airbnb, Journal of Business Research, 88, pp.187-196.

19. Pesonen, J., Laukkanen, T., Komppula, R., 2011. Benefit Segmentation of Potential Wellbeing Tourists, Journal of Vacation Marketing 17(4), pp.303-314.

20.Pike, S., 2012. Destination Positioning Opportunities using Personal Values: Elicited through the Repertory Test with Laddering Analysis, Tourism Management 33 (1), pp.100-107

21. Ragavan, N.A., Subramoniana, H., Sharif, S.P., 2014. Procedia - Social and Behavioral Sciences 144, pp. 403-411.

22. Shoemaker, S., 1994. Segmenting the U.S. Travel Market According to Benefits Realized. Journal of Travel Research, 32(3), pp.8-21

23.Tkaczynski, A., Rundle-Thiele, S.R., Prebensen, N.K., 2015. Segmenting Potential Nature-Based Tourists Based on Temporal Factors: The Case of Norway, Journal of Travel Research, 54(2), pp.251-265. 